Cite as: Bouillon S, Connolly RM (2009) Carbon exchange among tropical coastal ecosystems. In: Nagelkerken I. Ecological connectivity among tropical coastal ecosystems. Springer, pp 45-70

\title{
Chapter 3 Carbon exchange among tropical coastal ecosystems
}

\author{
Steven Bouillon and Rod M. Connolly
}

Steven Bouillon: Vrije Universiteit Brussel, Department of Analytical and Environmental Chemistry, Pleinlaan 2, B-1050 Brussels, Belgium; and Netherlands Institute of Ecology, Centre for Estuarine and Marine Ecology (NIOO-KNAW), Yerseke, the Netherlands, e-mail: steven.bouillon@vub.ac.be, s.bouillon@nioo.knaw.nl

Rod M. Connolly: Australian Rivers Institute - Coasts and Estuaries, and School of Environment, Griffith University Gold Coast campus, Queensland 4222, Australia, e-mail: r.connolly@griffith.edu.au

\begin{abstract}
Tropical rivers provide about $60 \%$ of the global transport of organic and inorganic carbon from continents to the coastal zone. These inputs combine with organic material from productive mangrove forests, seagrass beds and coral reefs to make tropical coastal ecosystems important components in the global carbon cycle. Carbon exchange has been measured over multiple spatial scales, ranging from the transport and fate of terrestrial organic matter to the coastal zone, export of organic matter to the open ocean, exchange of leaf litter between mangroves and adjacent seagrass beds, to movement of carbon (at a scale of meters) between adjacent saltmarsh and mangrove habitats. Carbon is exchanged directly as particulate or dissolved material, or through migration of animals or through a series of predator-prey interactions known as trophic relay. This chapter first examines riverine carbon inputs to the tropical coastal zone, and how this material is processed in estuaries. The mechanisms and extent of carbon exchange among tropical coastal ecosystems is then discussed, showing their importance in ecosystem carbon budgets, and the implications for faunal and microbial communities.
\end{abstract}

\subsection{Introduction}

Tropical coastal ecosystems are often highly productive, and can receive organic matter from a variety of sources, such as riverine inputs, local production by phytoplankton, or vegetated systems (mangroves, seagrasses). Tropical rivers have a disproportionately high importance in the global delivery of organic and inorganic carbon to the coastal zone (Ludwig et al. 1996a), but biogeochemical processing and local inputs from primary production in the coastal zone can great- 
ly modify the quantity and composition of carbon. In-depth knowledge of carbon fluxes and transformations in the tropical coastal zone is therefore important for a finer constraining of global carbon budgets. Moreover, considering the rapid and global changes occurring in river flows and associated sediment and organic matter transport, coastal eutrophication and destruction of coastal ecosystems such as mangroves, seagrass beds and coral reefs, understanding the functioning of these systems and their interactions is important to be able to correctly assess the health of estuaries and coastal systems and predict the impact of climate change or anthropogenic disturbance.

Organic matter differs substantially in biochemical composition and availability to consumers, depending on whether it is imported by rivers or produced locally by various primary producers (plankton, seagrasses, macroalgae, and mangroves). Exchange of organic matter across ecosystem boundaries thus has important consequences for the availability of organic matter and the relative importance of burial, mineralization, and consumption by fauna. It has often been proposed that organic matter exported from tidal wetlands such as mangroves and salt marshes enhances secondary production in the coastal zone, thus contributing to fisheries production. The mechanisms involved now appear to be much more complex, however, and there is as yet little evidence for a direct trophic link between land-derived organic matter inputs and coastal zone fisheries in the tropics (e.g., see Lee 1995). Exchange of carbon has been studied over multiple spatial scales, ranging from the transport and fate of terrestrial organic matter to the coastal zone, export of organic matter to the open ocean, exchange of litter between mangroves and adjacent seagrass beds, to movement of carbon (at a scale of meters) between adjacent saltmarsh and mangrove habitats (Fig. 3.1).

This chapter attempts to summarize the available information on patterns of carbon movement and exchange, and to discuss the underlying mechanisms and consequences. We focus first on the riverine inputs of organic and inorganic carbon to the tropical coastal zone, synthesize available data on how this material is processed in estuaries, and explain how this differs from temperate estuaries. The second part of this chapter discusses the exchange of carbon among various tropical coastal ecosystems, its importance in understanding ecosystem carbon budgets, and the implications of carbon exchange for faunal and microbial communities. 


\subsection{Riverine carbon transport to the tropical coastal zone}

\subsubsection{Fluxes, composition, and fate of riverine organic matter}

The global delivery of organic carbon $(\mathrm{C})$ to the world's oceans is estimated to be in the order of 0.3 to $0.5 \mathrm{Pg} \mathrm{C} \mathrm{y}^{-1}\left(1 \mathrm{Pg}=10^{12} \mathrm{~g}\right)$ (e.g., Ludwig et al. 1996a, 1996b, Schlünz and Schneider 2000), partitioned almost equally between dissolved and particulate organic carbon (DOC and POC). Riverine transport of inorganic carbon is globally estimated at approximately 0.3 to $0.4 \mathrm{Pg} \mathrm{C} \mathrm{y}^{-1}$ (Ludwig et al. 1996a). The tropics are thought to be responsible for about $60 \%$ of these fluxes (Ludwig et al. 1996a, Table 3.1), and are therefore disproportionately important in the global terrestrial - marine carbon transport when considering their areal $\mathrm{C}$ fluxes. We can thus estimate that for both inorganic and organic carbon, about 0.2 to $0.25 \mathrm{Pg} \mathrm{C}$ is delivered annually to the tropical coastal zone. It should be stressed, however, that relatively few empirical datasets exist on carbon export in tropical rivers, and that these estimates are to a large extent based on extrapolations of data from a limited number of catchments themselves based on empirical models relating catchment characteristics to carbon export. Hence, errors in either underlying data on catchment characteristics or the relationship with carbon export can bias these estimates.

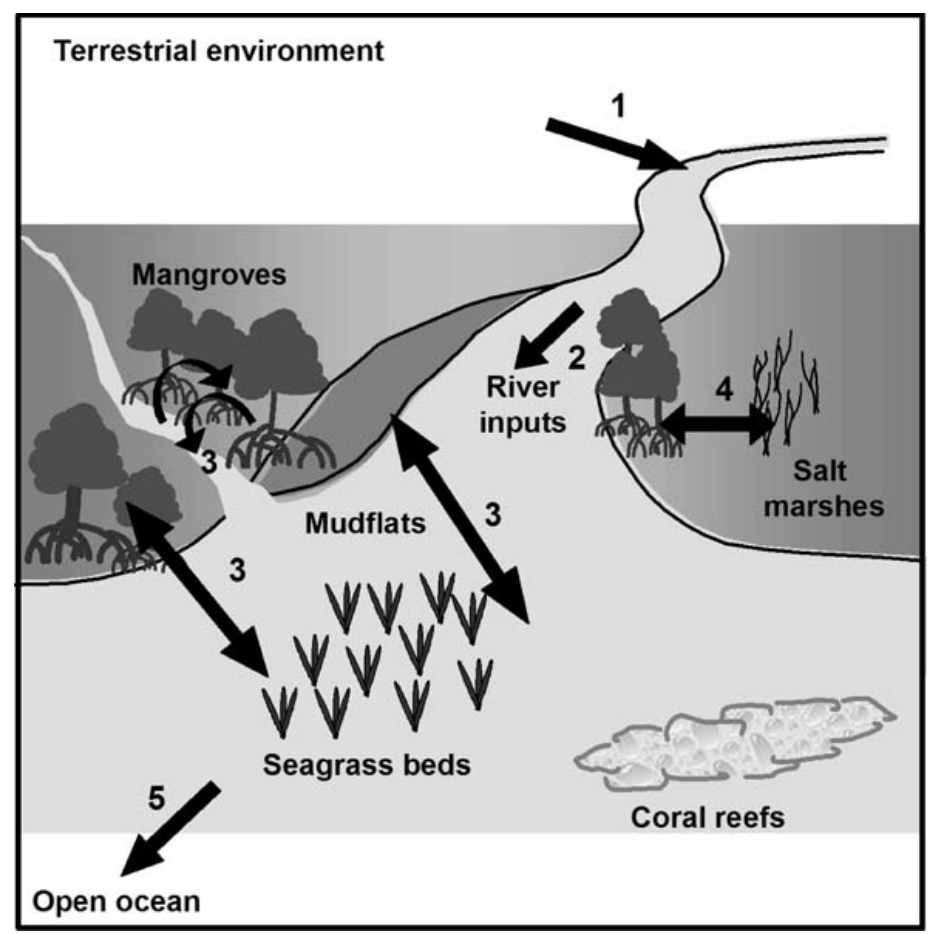

Fig. 3.1 Overview of some of the carbon exchange pathways considered in this chapter: (1) terrestrial inputs to rivers, (2) river inputs to the coastal zone, (3) exchange between intertidal and subtidal aquatic systems, (4) exchange between intertidal ecosystems, and (5) export towards them the open ocean 
Considering that certain geographical areas are responsible for a major part of these $\mathrm{C}$ fluxes, they are particularly important in determining the overall estimates of riverine C transport. Milliman et al. (1999), for example, estimated that six islands in the Indo-Pacific were responsible for about $20 \%$ of the global riverine sediment flux, whereas they represent only about $2 \%$ of the terrestrial area draining to the global ocean, and this may suggest that such areas may be similarly important in terms of carbon delivery. In line with this, Baum et al. (2007) recently estimated that DOC export from Indonesia could be equivalent to as much as $10 \%$ of the global riverine DOC flux to the coastal zone. Data from a number of east African estuaries (Bouillon et al. 2007a, b, Ralison et al. 2008), indicate that the relative export of inorganic carbon (as compared to organic carbon) is more than ten times higher than that predicted by the empirical model of Ludwig et al. (1996a). On a regional scale, it appears there is a substantial gap in data on the quantities and partitioning of carbon export. A further problem particularly relevant to quantifying carbon transport in tropical rivers is that (with some exceptions such as the Congo basin; Coynel et al. 2005), river discharge and associated carbon transport are often highly seasonal, with the majority of discharge often occurring in a very narrow time frame (e.g., Eyre 1998, Hung and Huang 2005).

Compositionally, organic carbon in rivers generally shows a strong link to the catchment vegetation and land use. In particular in turbid rivers where primary production is light-limited, organic matter from fringing vegetation, floodplains, and terrestrial soils (through runoff) dominates the river-borne organic matter pool. Nevertheless, not all vegetation types within a catchment contribute equally to riverine organic carbon inputs. In the Congo basin, for example, Coynel et al. (2005) found that forested sub-basins showed about three times higher area-specific fluxes of organic carbon than savannah-dominated basins. Similarly, a number of studies found a smaller contribution of C4-derived material (i.e., derived from tropical grasslands) in riverine organic matter than would be expected based on their relative cover in the rivers' catchment (Martinelli et al. 1999, Ralison et al. 2008). Inputs of organic carbon from (C4) grasslands appear to be more important during flood events or high flow periods (Martinelli et al.

Table 3.1 Estimates of global riverine carbon transport, as dissolved organic carbon (DOC), particulate organic carbon (POC) and dissolved inorganic carbon DIC), and the importance of the tropical zone in global carbon transport. These estimates are calculated from the data presented in Ludwig et al. (1996a). Note that DIC export is assumed to be equal to alkalinity export.

\begin{tabular}{|c|c|c|c|c|}
\hline & Flux $\left(10^{12} \mathrm{~g} \mathrm{C} \mathrm{y}^{-1}\right.$ & & Flux ratios & \\
\hline Region & POC & DOC DIC & POC/DOC & $\mathrm{DIC} /(\mathrm{DOC}+\mathrm{POC})$ \\
\hline Tropical, Atlantic Ocean & 45.3 & 59.174 .6 & 0.77 & 0.71 \\
\hline Tropical, Indian Ocean & 34.8 & 45.1 & 1.63 & 0.80 \\
\hline Tropical, Pacific Ocean & 33.9 & $26.8 \quad 60.3$ & 1.26 & 0.99 \\
\hline$\Sigma$ Tropical zone $\left(24^{\circ} \mathrm{S}-24^{\circ} \mathrm{N}\right)$ & 114.0 & 107.3180 .0 & 1.06 & 0.81 \\
\hline$\Sigma$ World & 178.6 & 179.8291 .8 & 0.99 & 0.81 \\
\hline $\begin{array}{l}\text { \% of global transport in the trop- } \\
\text { ics }\end{array}$ & 63.8 & $59.7 \quad 61.7$ & - & - \\
\hline
\end{tabular}


The estimates of carbon transport above (see Table 3.1) refer to what is delivered by rivers to the tropical coastal zone, but do not take into account possible changes occurring within estuaries, bays and lagoons, and thus do not necessarily reflect what is actually delivered to the open ocean. In these coastal systems, a range of changes can take place which greatly modify the quantity and composition of organic matter pools. Organic matter can be removed through burial, consumption or mineralization, and new inputs of organic matter can arise, in particular from the often very productive vegetated systems such as mangroves or seagrass beds. This will result in deviation from conservative behavior along the estuarine mixing gradient. Conservative mixing implies no loss or inputs along the estuarine gradient, and hence, a linear concentration gradient between freshwater and marine end-members (see also Chapter 13). Mixing scenarios can also be evaluated using $\delta^{13} \mathrm{C}$ signatures, whereby conservative mixing follows the general equation (described here for dissolved organic carbon):

$$
\delta^{13} C=\frac{\operatorname{Sal}\left(\mathrm{DOC}_{F} \delta^{13} C_{F}-\mathrm{DOC}_{M} \delta^{13} C_{M}\right)+\operatorname{Sal}_{F} \mathrm{DOC}_{M} \delta^{13} C_{M}-\operatorname{Sal}_{M} \mathrm{DOC}_{F} \delta^{13} C_{F}}{\operatorname{Sal}\left(\mathrm{DOC}_{F}-\mathrm{DOC}_{M}\right)+\operatorname{Sal}_{F} \mathrm{DOC}_{M}-\mathrm{Sal}_{M} \mathrm{DOC}_{F}}
$$

whereby: Sal = the sample salinity, $\mathrm{DOC}_{\mathrm{F}} \delta^{13} \mathrm{C}_{\mathrm{F}}=$ the DOC concentration and stable isotope composition at the freshwater or least saline end-member, $\mathrm{DOC}_{\mathrm{M}} \delta^{13 \mathrm{C}} \mathrm{C}_{\mathrm{M}}=$ the DOC concentration and stable isotope composition at the marine end-member.

Examples of such non-conservative behavior are shown in Fig. 3.2, where DOC and $\delta^{13} C_{\text {DOC }}$ profiles are shown for two contrasting estuaries. The DOC profile for Mtoni estuary (Tanzania) shows clear net inputs of DOC along the estuarine gradient, i.e., with DOC data points above the conservative mixing line (Fig. 3.2a). The corresponding $\delta^{13} \mathrm{C}_{\text {DOC }}$ profile (Fig. 3.2b) indicates that the inputs of DOC in this estuary have a ${ }^{13} \mathrm{C}$-depleted signature, consistent with the expected DOC inputs from mangroves, which occur along the length of the salinity profile measured (see also Machiwa 1999). The DOC profile from the Tien river estuary (Mekong delta, Vietnam), where no mangrove vegetation is present, shows a contrasting pattern, with net losses of DOC along the salinity gradient, i.e., most DOC data points below the conservative mixing line (Fig. 3.2c). The $\delta^{13} \mathrm{C}_{\text {DOC }}$ profile for this site (Fig. 3.2d) is similar in shape to the one from Mtoni and indicates that this loss of DOC coincides with a depletion in ${ }^{13} \mathrm{C}$ of the remaining DOC pool, most likely suggesting selective degradation of a more ${ }^{13} \mathrm{C}$ enriched fraction of DOC. 

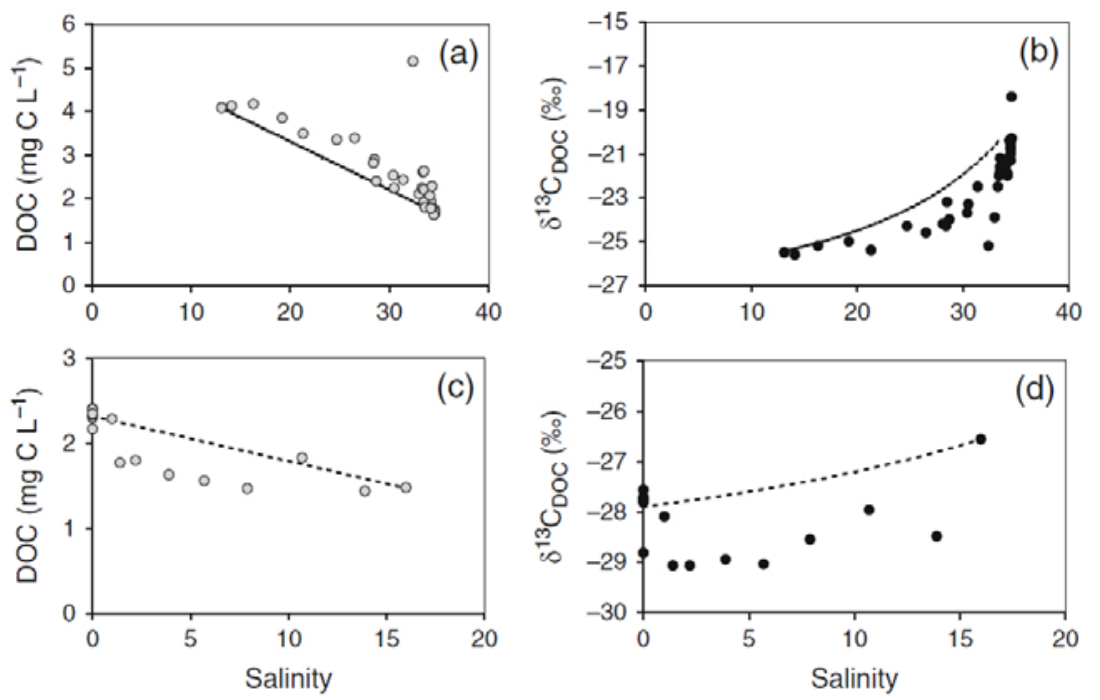

Fig. 3.2 Examples of non-conservative behavior of dissolved organic carbon (DOC) in tropical estuaries showing profiles of DOC (a) and $\delta^{13} \mathrm{C}_{\mathrm{DOC}}$ (b) from Mtoni estuary (Tanzania) and from Tien estuary (Mekong Delta, Vietnam) (c, d). Source: S. Bouillon and A.V. Borges, unpubl. data. Dotted lines show the patterns expected for conservative mixing between the least saline and most saline end-members.

The behavior of DOC in estuaries may also change seasonally: Dittmar and Lara (2001a), for example, reported DOC profiles for the Caeté estuary (Brazil) which show both conservative characteristics and non-conservative behavior during different parts of the year. Similarly, Young et al. (2005) report DOC profiles from a tropical seagrass-covered and mangrove-fringed lagoon which suggest both net losses of DOC or net inputs during the mixing process, depending on the season.

River flows are often highly seasonal in tropical regions (e.g., Vance et al. 1998), with the exception of systems with large catchment areas along the equator such as the Congo river basin (see Coynel et al. 2005), and the composition and degradation status of organic matter can thus be distinctly seasonal (e.g., Ford et al. 2005, Dai and Sun 2007). During low flow periods, estuaries have much longer residence times, with consequently much higher potential for biogeochemical processes to modify the quantity and composition of organic matter and nutrients (Eyre 1998). Conversely, during periods of high flow, large estuarine plumes may develop which allow for riverine material to be transported further offshore and with less processing of organic carbon within the estuary (e.g., Ford et al. 2005). In coastal bays, in contrast, the relative contribution of terrestrial material to the overall organic carbon pool may be more substantial during the dry season. Xu and Jaffé (2007) reported such a pattern for Florida Bay, which was ascribed to reduced primary production within the bay during the dry season. The 
fate of riverine organic matter is thus likely to differ substantially during high and low flow periods, although few studies have actually documented such patterns.

The delivery of terrestrial organic matter to offshore waters is important in at least some circumstances. Extensive offshore delivery has been demonstrated for a number of large river systems such as the Congo river (e.g., Shefuss et al. 2004), the Fly River in Papua New Guinea (Goñi et al. 2006) and the Ganges-Brahmaputra river system (Galy et al. 2007), and from tidal wetlands such as the extensive mangroves along the coast of Brazil (Dittmar et al. 2006). Carbon delivery from smaller rivers discharging to open coasts is probably less important. In Australia, for example, where small estuarine plumes punctuate long stretches of sandy coastline, a conservative tracer showed that estuarine particulates were distributed over only a small area at the estuarine mouth, and terrestrial carbon contributions had little impact on background coastal sources (Gaston et al. 2006).

The contribution of terrestrial carbon to estuarine metabolism and local foodwebs has received relatively little attention so far, in part due to the difficulty of detecting its incorporation. Stable isotope signatures of terrestrial C3 plants overlap with those of often-present local lateral inputs (e.g., mangroves) and may also overlap with those of in situ aquatic producers. In systems where organic matter derived from catchment $\mathrm{C} 4$ vegetation contributes significantly to the riverine carbon load, however, it becomes much more feasible to calculate terrestrial carbon contribution. Surprisingly, data from such systems suggest that terrestrial organic matter can be a major source of carbon even in intertidal mangrove sediments, and contributes equally to sedimentary bacterial communities (up to 40$50 \%$; see Bouillon et al. 2007b, Ralison et al. in review). The extent to which communities of higher organisms such as invertebrates and fish rely on terrestrial organic matter has recently become a topic of study in temperate waters (e.g., Darnaude et al. 2004), but in tropical systems this has to our knowledge not been studied in detail, although this may be a promising line of future work.

\subsubsection{Effects of human perturbations}

\subsubsection{Changing river flows and catchment land-uses}

Freshwater flows from rivers into estuaries and ultimately into coastal waters are fundamentally important to carbon transfer. Dissolved and particulate carbon is transported directly in these waters. Freshwater flows also affect carbon movement indirectly, through their effects on salinity in estuaries that alter distributions of coastal pants and the migratory movements of aquatic animals. Freshwater surface and groundwater flow is an important factor, for example, in the distribution of mangrove (Hutchings and Saenger 1987) and saltmarsh plants (Pennings and Bertness 2001). Anthropogenic changes to freshwater flows from rivers therefore alter carbon transfer within and among systems via several differ- 
ent mechanisms. Fresh water is now in such short supply that a global shortage is looming (Postel 2000) and increased harvesting is a certainty. There is thus a need for strong, science-based decisions about water releases from dams to maintain ecosystem health (environmental flows) under pressing political realities (Arthington et al. 2006).

River flows discharging to the sea generally stimulate productivity (Gillanders and Kingsford 2002). In tropical systems, very clear correlations have been found between river flow and fisheries harvests. Flow in two different river systems on the east coast of Australia, for example, match annual fisheries catches, either with or without a time lag. Flows in the Fitzroy River are correlated with increased survival and growth of cohorts of barramundi (Lates calcarifer), and catches of this species are higher several years later (Staunton-Smith et al. 2004). Summer flows in the Logan River are positively correlated with catches of fish, crabs and prawns (Loneragan and Bunn 1999). This effect is detected in the same year, and might simply be a result of increased harvesting of recruits into fishing zones, as is probably the case for banana prawns in the Gulf of Carpentaria, Australia (Vance et al. 1998). Another mechanism which has been suggested is that increased terrestrial organic matter loads to coastal waters increases the abundance of meiofauna and macrofauna, the main prey of the fisheries species (Loneragan and Bunn 1999).

Changing land-use in coastal catchments also affects the amount and nature of organic matter arriving in estuaries and coastal waters. In China, carbon loads from urban and agricultural areas are so now so prevalent that inputs from local mangrove forests have become unimportant in food webs (Lee 2000). The change from forest to agriculture over the last 200 years in catchments adjacent to the Great Barrier Reef, for example, is thought to have increased sediment delivery to the reef about four-fold (see Furnas 2003, cited in Ford et al. 2005), and presumably organic loads along with it.

\subsubsection{Effects of climate change on carbon exchange}

Patterns in carbon exchange among tropical systems sit within an overarching position of global carbon cycles (Cloern 2001). Carbon is central to the topical issue of climate change. Although the effects of climate change on marine systems has been considered (Poloczanska et al. 2007), we have been unable to find any studies of how climate change might affect carbon exchanges at the landsea interface. The most certain effect of recent and predicted acceleration in changes to climate on carbon exchange will be through altered rainfall patterns and therefore river flows (Table 3.1). Where rainfall is reduced, the overall delivery of organic matter to estuaries and the coast will be lower. Conversely, where increased rainfall is predicted, we can also predict a greater contribution of terrestrial organic matter to the coastal zone. Overlaying those effects will be the increased variability in rainfall (Poloczanska et al. 2007), with more severe weather events leading to rainfall peaks of greater magnitude and frequency than currently occur. Extreme flow events will likely lead to large pulses of input of terrestrial 
matter, and as discussed above, probably to an increased importance of C4 material from agriculture.

The ramifications of climate change will, however, be much broader than this. The extent and type of land-use in coastal catchments will presumably be altered, through changes in agricultural activities and urbanization (Cloern 2001). Ultimately this will alter carbon inputs to estuaries and coastal waters (as discussed above).

\subsection{Exchange of carbon between vegetated tropical systems and adjacent systems}

\subsubsection{Transfer of carbon from intertidal to subtidal - outwelling}

Concepts about carbon transfer among nearshore systems are dominated by the theory of net transfer of carbon from shallow, estuarine habitats to deeper, adjacent waters. This 'Outwelling hypothesis' is based on observations, from saltmarsh systems on the Atlantic coast of North America, that secondary production in adjacent waters could only be sustained if the marsh exports energy (Odum 1968). For tropical systems, this translates as a potential dependency on mangrove-derived organic matter for secondary production in adjacent systems. The export of particulate and dissolved organic carbon from mangroves has received considerable attention, even though the number of quantitative studies is still rather limited to allow for an accurate assessment of organic carbon export on a global scale (e.g., Bouillon et al. 2008b), and the assessment of export rates is hampered by methodological difficulties (e.g., Ayukai et al. 1998; see also Chapter 13, Section 13.4). Some stable isotope studies show that invertebrates and fish in habitats within hundreds of meters of mangroves obtain carbon from the mangrove forest (Harrigan et al. 1989, Lugendo et al. 2007), although others have not found this (e.g., Connolly et al. 2005, see also Section 3.3.1.5). Lack of influence has been definitively demonstrated at sites further away (Lee 1995). Mangroves may serve both as exporters of organic and inorganic carbon, but also import organic matter during tidal inundation, and assessing the net balance of these processes is not straightforward.

Organic matter from vegetated, intertidal habitats such as mangroves in tropical waters might be exported via three main avenues (Fig. 3.3): 1) dissolved or particulate matter, 2) through migration of animals from intertidal to subtidal waters, and 3) through a series of predator-prey interactions known as trophic relay (Kneib 1997). Each of these pathways is discussed in more detail below. Pathways of DOC, POC, and macro-litter export are likely to differ substantially. 
For DOC, a number of studies have stressed the importance of sediment-water exchange and pore-water flow as vectors for DOC exchange with estuarine or tidal creek waters (e.g., Ovalle et al. 1999, Dittmar and Lara 2001b, Schwendenmann et al. 2006, Bouillon et al. 2007c). Particulate organic carbon, in contrast, appears to be influenced more by water current velocities and runoff (e.g., Twilley 1985). The importance of tidal dynamics was also suggested by Twilley (1985) who compared organic carbon export in different types of mangrove forests and found that the cumulative tidal amplitude is a main driver of the magnitude of total organic carbon export.

\subsubsection{Exchange of DOC and POC}

Our understanding of organic carbon exchange in mangroves comes from a relatively small number of studies: a recent review documents only six and seven estimates for DOC and POC export, respectively, and 11 estimates for total organic carbon export (Bouillon et al. 2008b). It should also be kept in mind that these estimates have been derived using a variety of approaches, including tidal measurements of organic carbon combined with water current measurements, and flux estimates using flow-through flumes (see also Chapter 13). Global estimates of organic carbon export (POC+DOC) from mangroves are in the order of about $250 \mathrm{~g} \mathrm{C} \mathrm{m}^{-2} \mathrm{y}^{-1}$, with DOC and POC each representing about half of this flux. Together, this would amount to approximately $20 \%$ of the net primary production by mangroves, although it must be stressed that our current understanding of carbon cycling in mangroves leaves a large uncertainty in assessing an overall $\mathrm{C}$ budget for these systems (see Bouillon et al. 2008b). One major shortcoming of most current flux estimates (apart from the limited number of data used to extrapolate to a global level) is the fact that they rarely include a source characterization, and thus do not differentiate between organic carbon fluxes of mangrove origin and those of other potential carbon sources. In that respect, current flux data could be inherently biased and provide an overestimate of actual organic carbon fluxes from mangroves. Source characterization could be particularly important to integrated POC flux measurements, since it is known that mangroves (and other intertidal systems) can trap significant amounts of particulate material, including organic carbon often of non-mangrove origin, during tidal inundation (e.g., Middelburg et al. 1996, Bouillon et al. 2003). Moreover, import and export fluxes of POC (of different origin) can be closely balanced (e.g., Ayukai et al. 1998), leaving only a small residual net flux. For dissolved organic carbon, there are indeed studies which report a net influx, rather than efflux of organic carbon in certain mangrove systems. The flume experiments by Davis et al. (2001) in fringing mangroves along the Taylor River, for example, show that despite seasonal variations, DOC was generally imported from the water column, while TOC showed only small net fluxes, which ranged from import to export. Boto and Wellington (1988) also noted net DOC uptake in mangrove sediments in Coral Creek in northern Australia. 


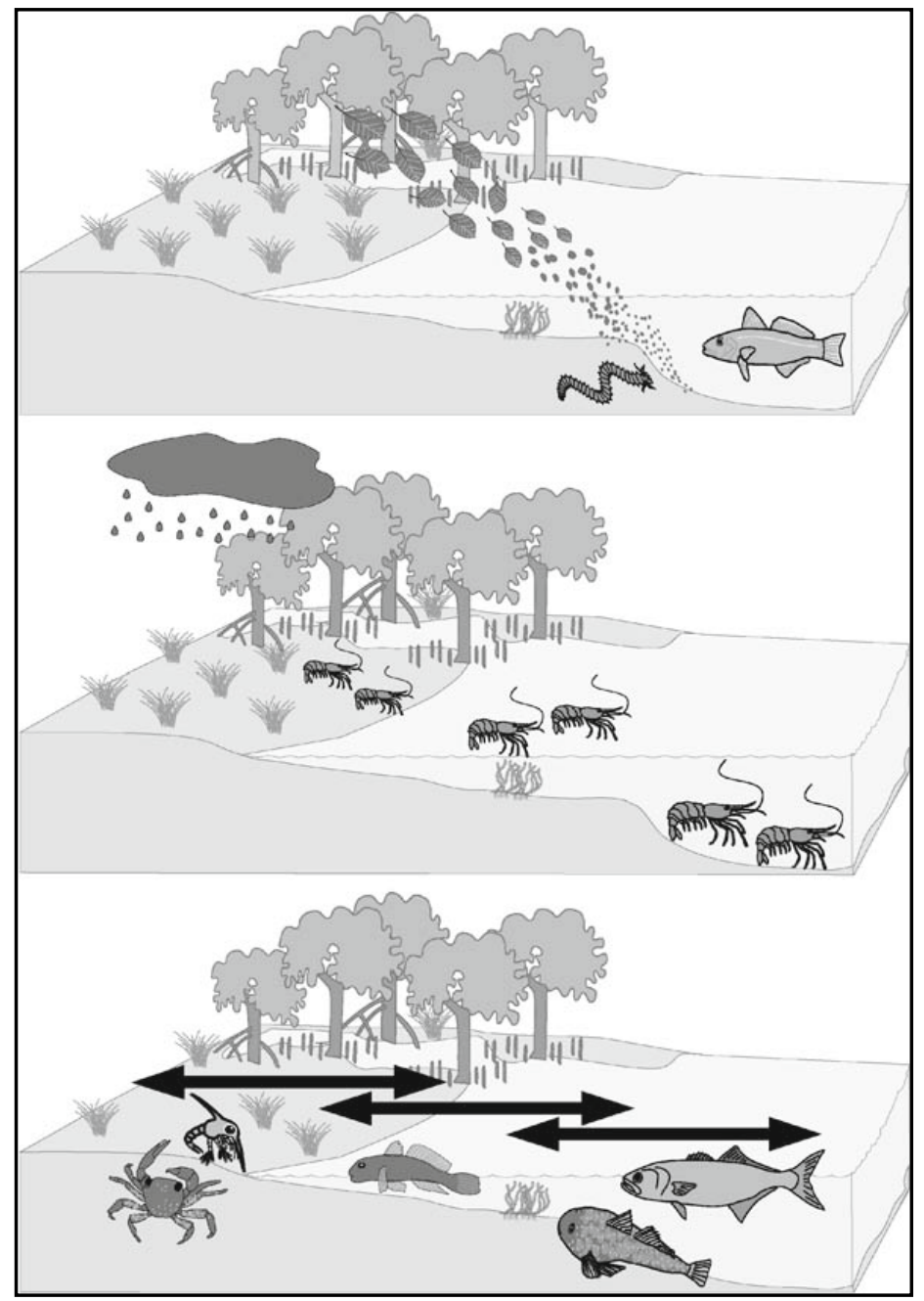

Fig. 3.3 Three mechanisms of transfer of organic matter from mangroves to food webs in deeper water (from Connolly and Lee 2007). Detrital transport includes movement of particulate and dissolved organic matter. Ontogenetic migration is movement in migrating animals such as banana prawns (Fenneropenaeus merguiensis). Trophic relay (Kneib 1997) involves a series of predator-prey interactions; in Australia, for example, crabs and their larvae which are high on the shore are eaten by fish such as glassfish (Ambassidae), gobies (Gobiidae) and juvenile mullet (Mugilidae), which in turn are preyed upon by fish such as flathead (Platycephalidae) and tailor (Pomatomidae).

One aspect of the study by Davis et al. (2001) is that their flumes were in continuously submerged mangroves, along the flow-path of a channel, in a non-tidal system, and any influence of the tidal pumping phenomenon cannot be ascertained. Since tidal pumping is likely an important mechanism for solute export 
(e.g., Dittmar and Lara 2001a, Schwendenmann et al. 2006, Bouillon et al. 2007c), DOC export in non-tidal systems may be significantly lower than in most other mangrove settings. In general, tidal hydrology and cumulative tidal amplitude would appear to be important determinants of the degree of organic carbon export. Subsequently, carbon export has been suggested to be higher in riverine forests than in fringe and basin forests (see Twilley 1985), and higher during periods of higher freshwater runoff in estuarine systems (Sutula et al. 2003). Similarly, Romigh et al. (2006) reported a seasonal pattern in DOC fluxes (i.e., periods with net export as well as periods with net import of DOC) consistent with a strong influence of freshwater discharge and tidal amplitude on DOC fluxes.

\subsubsection{Exchange of dissolved inorganic carbon}

The focus on carbon exchange in tropical coastal ecosystems has so far been directed to organic carbon species, but to our knowledge no studies have attempted to directly quantify exchange of dissolved inorganic carbon (DIC). Nevertheless, tropical coastal ecosystems are sites with intense cycling of inorganic carbon, in particular the classical mangrove-seagrass-coral reef sequence. Mangroves are known for their intense mineralization and high $\mathrm{CO}_{2}$ exchange (e.g., Borges et al. 2003). Tropical seagrass beds can attain very high primary production rates (e.g., Hemminga et al. 1994) resulting in significant lowering of $\mathrm{pCO}_{2}$ levels in the water column (Bouillon et al. 2007a). Coral reefs, on the other hand, are a major contributor to overall oceanic $\mathrm{CaCO}_{3}$ production (Gattuso et al. 1998). A recent comparison of DIC and DOC profiles from a number of tidal mangrove creeks and estuaries indicated that the lateral inputs of DIC from the mangroves was on average about eight times higher than for DOC (Bouillon et al. 2008b). If this is confirmed in other systems and/or through direct quantitative estimates of DIC exchange, this would imply that the mineralization of mangrove carbon and its subsequent export as DIC is substantially higher than the export of mangrovederived material as organic carbon.

\subsubsection{Migration and trophic relay}

The transfer of energy from nearshore to offshore waters in migrating animals is an often overlooked but potentially important mechanism (Kneib 2000). Many important fisheries species, including crustaceans such as crabs and prawns, arrive in estuarine waters as larvae or post-larvae, then grow in the upper estuary, before migrating as larger animals (with their carbon) to the sea. In tropical waters, migration of key species such as banana prawns (Fenneropenaeus merguiensis) is often strongly seasonal. In the Gulf of Carpentaria, northern Australia, this results from strong freshwater flows through estuaries (Vance et al. 1998). In peninsular Malaysia, where the seasonality of migration for this same species is less pronounced because of more evenly distributed rainfall, the transfer of carbon in the body of animals is still important, because there is the same pronounced net 
migration out of estuary (Ahmad Adnan et al. 2002). In southern USA, carbon transfer has been inferred from stable isotopes studies showing the movement of substantial numbers of pink shrimp (Farfantepenaeus duorarum) from seagrass meadows to unvegetated fisheries areas (Fry et al. 1999). The total carbon load transferred in this way has not been estimated, and it might ultimately prove to be small relative to particulate and dissolved transfer. This energy source is, however, probably important in coastal food webs because the animals that migrate are highly likely to be predated, and the link with food webs is therefore much more direct than for DOC and POC exported from estuaries.

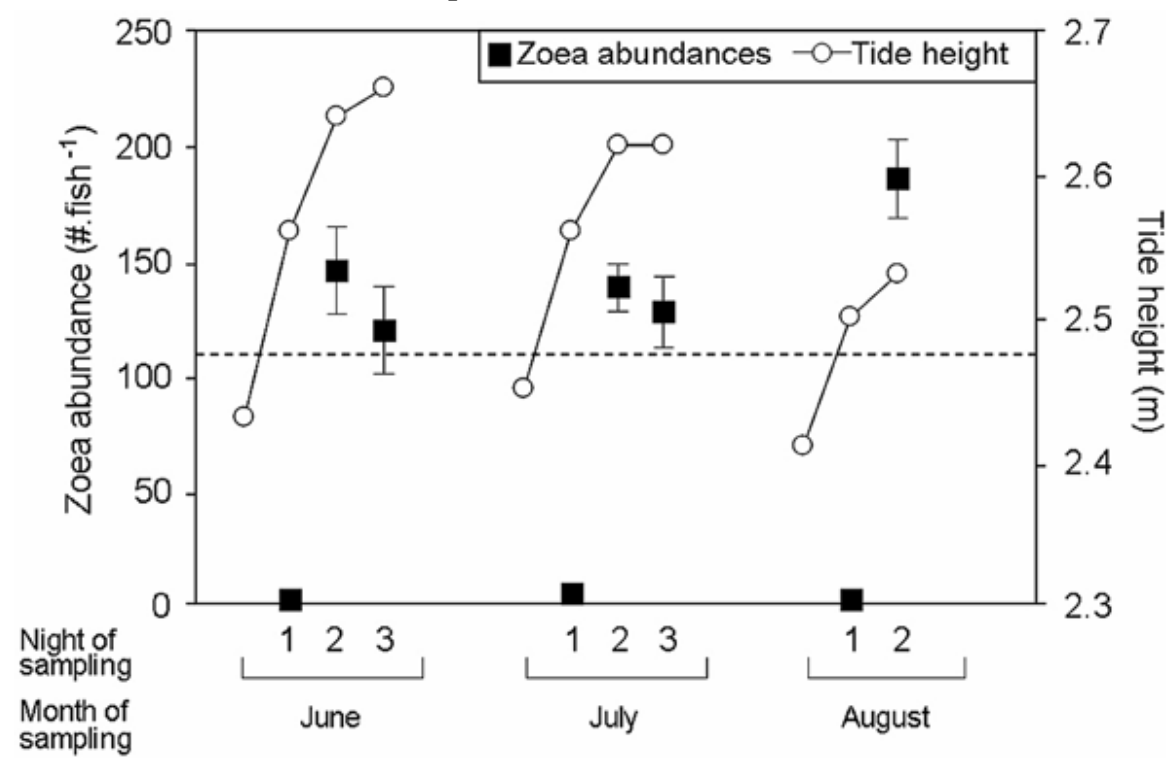

Fig. 3.4 Crab zoea abundances (mean $\pm \mathrm{SE}$ ) in glassfish (Ambassis jacksoniensis) stomachs after feeding on subtropical saltmarsh (data from Hollingsworth and Connolly 2006). In each monthly cycle, fish do not feed on zoea on the first night a marsh is flooded but do so on subsequent nights. Tidal height is shown for each night of sampling and the night before sampling. Tidal height at which marsh is inundated $(2.48 \mathrm{~m})$ is shown by dotted line.

The phenomenon of trophic relay was first described from temperate saltmarshes, which have small, resident fish and crustacean species that are preyed upon by somewhat larger fish visiting the marsh as transients at high tide. These predators are themselves potentially preyed upon by larger piscivorous fish, thus producing the effect of a relay system that transfers energy from shallow to deeper waters (Kneib 1997). There is preliminary evidence that this concept also applies in tropical systems. For example, glassfish (Ambassis jacksoniensis) have been shown to feed on huge quantities of shore crab larvae on a subtropical marsh in Queensland (Hollingsworth and Connolly 2006). Such marshes are inundated only on spring tides, and inundation has an extraordinary effect on the pattern of feed- 
ing by fish. Glassfish visiting the marsh on the first night of a tidal cycle feed only lightly, eating a small number of a range of prey types. This inundation apparently acts as a cue for shore crabs to release larvae, and on subsequent nights, glassfish eat an average of 100 to 200 crab larvae per fish (Fig. 3.4). Glassfish are a small, extremely abundant schooling species, and would be preyed upon by many of the larger fish in channels adjacent to these subtropical marshes (Baker and Sheaves 2005). Substantial effort has recently been aimed at understanding the trophic structure of fish communities in tropical systems (Nagelkerken and van der Velde 2004). Although the extent of piscivory generally remains to be demonstrated (Sheaves and Molony 2000), the first studies combining food web and movement analysis show that trophic relay is potentially very important (Kruitwagen et al. 2007, Lugendo et al. 2007) .

\subsubsection{Effects on organic matter transfer on food webs and ecological structure}

The transport and accumulation of macro-litter in adjacent systems has a number of impacts on the sedimentary environment and faunal communities, but few studies have documented such effects. Daniel and Robertson (1990) suggested that the presence and abundance of exported mangrove detritus had a positive influence on certain groups of macrobenthos such as penaeid shrimps, e.g., by serving as a shelter from predation. For benthic microfauna, in contrast, Alongi (1990) did not find convincing evidence that exported mangrove detritus enhanced the densities of flagellates, ciliates or protozoa. In a long-term experiment in which mangrove litter was added to a microcosm with a sandy substrate, Lee (1999) found no marked influence of litter addition to macrofaunal biomass, but species richness and diversity decreased with increasing litter inputs. The latter could be due to the negative effects of tannins leaching from litter (Alongi 1987, Lee 1999). Organic carbon in sediments can obviously serve as an important food source for organisms, but the oxygen depletion and accumulation of toxic by-products occurring when high loads of organic matter are delivered to sediments has been shown to result in potential decreases in the abundance and diversity of benthic fauna (Hyland et al. 2005). Although initial reports suggested an important direct trophic role for mangrove organic matter in adjacent aquatic foodwebs (Odum and Heald 1975), most later studies found little or no unambiguous evidence for such a role and suggest that the contribution of mangrove-derived carbon to nearshore foodwebs is minimal (see Bouillon et al. 2008a, and Section 3.3.1.5). Considering the importance of dissolved organic matter exchange, the lack of data on the fate of DOC and DON (dissolved organic nitrogen) is striking, and presents an important area for future work. The experiments by Dittmar et al. (2006) indicated that DOC from mangrove pore-waters is partly photo-degraded and chemically modified, but that a major part remains after several weeks of incubation in the presence of a natural bacterial community. This suggests that part of the mangrove-derived 
DOC pool is sufficiently refractory to be dispersed over large areas when hydrodynamic conditions allow.

The quality of organic matter is also important as a determinant of consequences of carbon transport for fauna. For example, excessive labile organic matter (e.g., from shrimp farming) can lead to extensive hypoxia zones (Chua 1992), whereas more refractory organic matter can accumulate in marine sediments (POC) or can be transported in dissolved form (DOC) offshore (Alongi and Christoffersen 1992).

\subsubsection{Detecting 'false positives' in outwelling studies - avoiding pitfalls in stable isotope gradient analysis}

A large number of studies have used stable isotope ratios to infer the relative contribution of carbon from intertidal vegetation, particularly mangroves, and other potential sources to the sedimentary or suspended organic matter pool (e.g., Machiwa 2000, Kuramoto et al. 2001, Thimdee et al. 2003). A common strategy has been to relate variations in $\delta^{13} \mathrm{C}$ values of POC to the admixture of mangrove-derived carbon and 'marine' phytoplankton, where the latter is characterized by typical $\delta^{13} \mathrm{C}$ values of about -20 to $-18 \%$ o (e.g., Rezende et al. 1990, Chong et al. 2001). This oversimplified approach has a major shortcoming because it is based on an assumption that phytoplankton within estuaries or mangrove creeks has a $\delta^{13} \mathrm{C}$ signature similar to that of marine phytoplankton, which is unlikely since mangrove creeks and estuaries typically have $\delta^{13} \mathrm{C}$ signatures for DIC which are distinctly depleted in ${ }^{13} \mathrm{C}$ by 6 to $8 \%$ (Bouillon et al. 2008a). Primary producers in the water column are therefore expected to show a similar depletion relative to producers from open marine systems, and the same holds for benthic microalgae (Guest et al. 2004).

The depleted $\delta^{13} \mathrm{C}$ values of DIC near mangroves also affects values of benthic macrophytes such as seagrasses. Seagrass $\delta^{13} \mathrm{C}$ values usually range between -16 and -12\%o (Hemminga and Mateo 1996), but ${ }^{13} \mathrm{C}$ values of seagrasses adjacent to mangrove forests typically show a gradient of more depleted values close to the mangroves, becoming more enriched with increasing distance towards the sea (e.g., a range of almost $10 \%$ over $<4 \mathrm{~km}$ distance found by Hemminga et al. (1994) and Marguillier et al. (1997). Studies that overlook the DIC isotope gradient with increasing distance offshore from mangroves therefore also overlook a probable gradient in isotope ratios of primary producers with distance offshore. Any gradient in isotope ratios of particulate carbon or even in animal tissues described in such studies might therefore provide 'false positives' in their test of the importance of mangrove carbon.

The isotopic depletion of the DIC pool near mangroves, and its effect on other local autotrophs, means that reliance on any autotroph will look like a mangrove contribution to food webs adjacent to mangroves in isotope gradient studies. It is important, therefore, to adopt specialized strategies to overcome this challenge in studies of potential outwelling. First, isotope values of potential alternative sources should be measured intensively and at a fine spatial scale. If plankton 
cannot be properly collected, spatially intensive DIC sampling provides a realistic alternative. Second, because carbon isotope measurements alone often cannot resolve the contribution of various sources to the POC pool, a combination of isotopes with other tracers should be considered (such as POC/PN ratios, e.g., Goonnea et al. 2004; POC/Chl. $a$ ratios, e.g., Cifuentes et al. 1996; or other biochemical tracers such as lignin-derived phenols, Dittmar et al. 2001, see also Chapter 13).

\subsubsection{Transfer of carbon to intertidal habitats - inwelling}

\subsubsection{Seagrass to mangroves}

The role of macrolitter in material exchange has been poorly studied in tropical coastal systems, and represents an important gap in our knowledge, since the few available studies suggest that the quantities of floating or suspended macrolitter can be high in comparison to the normal POC or DOC concentrations.

Fig. 3.5 Deposition of seagrass litter in intertidal

Avicennia marina forests in Gazi Bay (Kenya) (a),

deposition of the macroalgae Ulva spp. in Sonneratia alba mangroves in Mtoni Estuary,Dar es Salaam (Tanzania) (b)

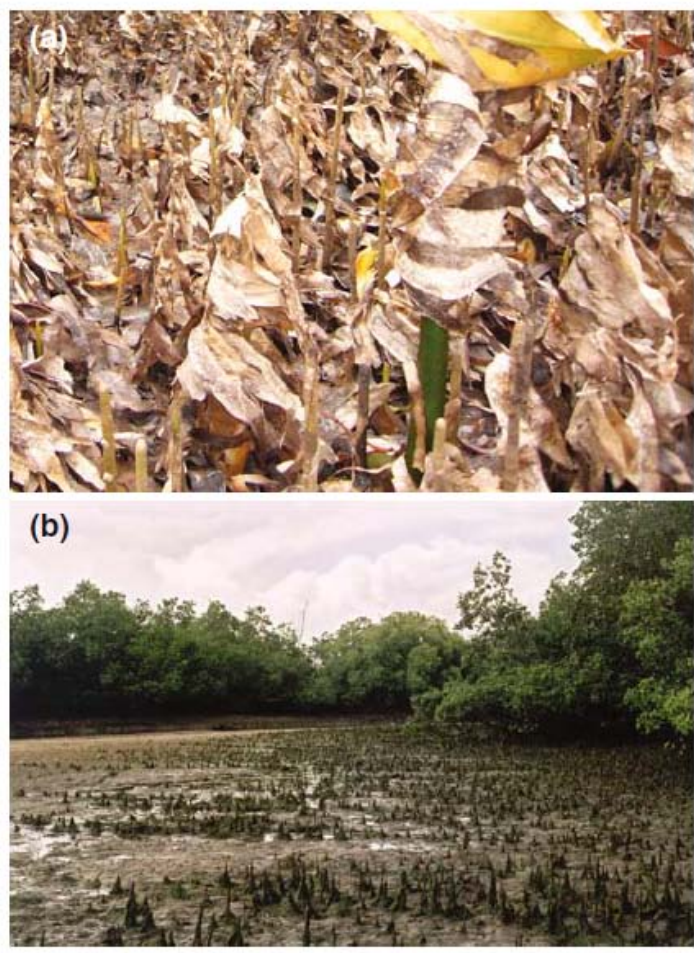


Slim et al. (1996) documented tidal transport of seagrass, mangrove, and macroalgal litter in a Kenyan bay. They found clear evidence for bidirectional transport of macrolitter, with a dominance of seagrass litter during both ebb and flood periods, but mangrove litter being more important during ebb than during flood periods. The accumulation of mangrove-derived material in this system has also been demonstrated based on organic carbon and stable isotope evidence (Hemminga et al. 1994, Bouillon et al. 2004). The deposition of litter in intertidal mangroves can be highly conspicuous in sites close to seagrass beds or where macroalgae are abundant (Fig. 3.5), and is also evident based on stable isotope data in bulk sediments which are often distinctly different from that of the dominant local vegetation (Middelburg et al. 1996, Bouillon et al. 2004, Fig. 3.6) and in the distribution pattern of n-alkanes in mangrove sediments close to the seagrass beds (P.V. Khoi and S. Bouillon, unpubl. data). Wooller et al. (2003) found the sediment organic matter in Laguncularia mangroves in Twin Cays (Belize) often to be dominated by non-mangrove sources, including seagrass material, as evidenced by some sites having high $\delta^{13} \mathrm{C}$ signatures combined with high $\mathrm{C} / \mathrm{N}$ ratios, consistent with those of Thalassia sp. from adjacent seagrass systems. Massive deposits of seagrass material have also been reported on tropical sandy beaches (Hemminga et al. 1991) and in intertidal flats (de Boer 2000), but little is known on the fate of this material and its potential trophic importance in these unvegetated systems.

\subsubsection{Seagrass to mudflats}

For shallow sand and mud flats, recent experimental work in temperate waters has resulted in a new conceptualization of food webs. Deliberate ${ }^{13} \mathrm{C}$ tracer experiments on the intertidal flats of northern Europe clearly show that benthic microalgae in the sediment are a major contributor to food webs (Middelburg et al. 2000). This has formed part of the more general realization that benthic microalgae are highly productive and easily assimilated in a food web context (MacIntyre et al. 1996).

In tropical Australian systems, there is evidence from fatty acid studies that benthic microalgae make at least some contribution to the nutrition of invertebrates (Meziane et al. 2006). On the other hand, carbon isotope evidence from the same mudflats shows a strong reliance on allochthonous carbon from adjacent seagrass meadows (Melville and Connolly 2003). This transfer of organic material from seagrass meadows to mud flats is further supported by recent results for the commercially-important portunid mud crab, Scylla serrata. Mud crabs generally have relatively enriched carbon isotope ratios, showing reliance on organic matter from either seagrass meadows or saltmarsh grass. Mud crab ratios, however, show 


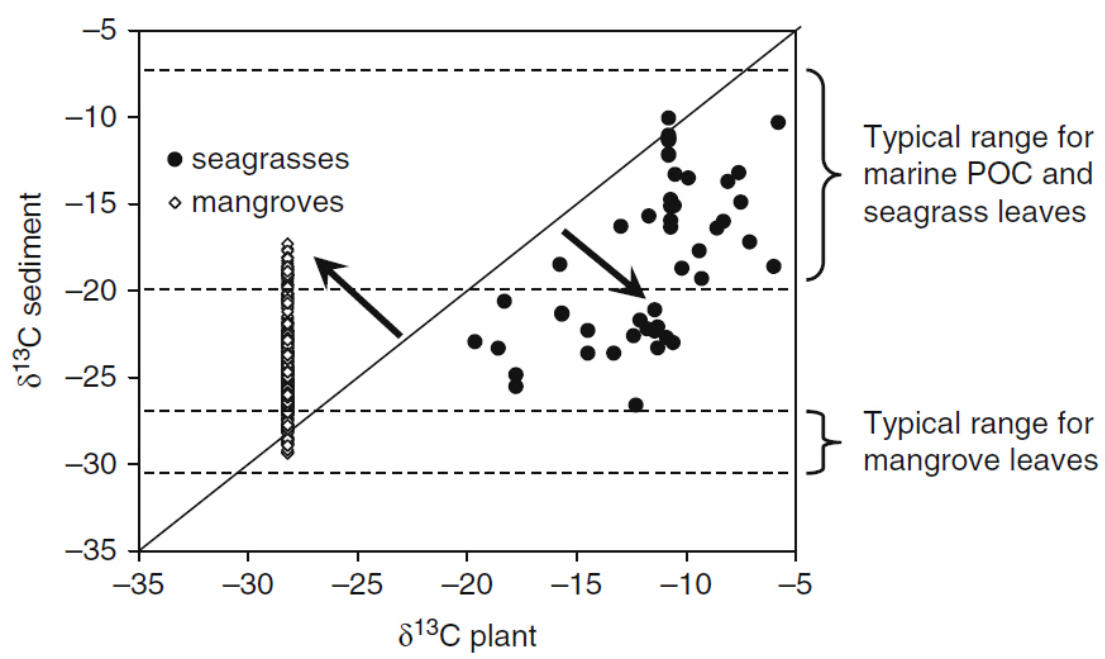

Fig. 3.6 Comparison of sediment organic carbon $\delta^{13} \mathrm{C}$ signatures with those of the dominant seagrass species (data for tropical and subtropical systems only) or mangroves. For mangroves, we used a global average $\delta^{13} \mathrm{C}$ value for plant material of -28.2\% (see Bouillon et al. 2007d). For data sources for seagrass systems,see Bouillon et al. (2004); data for mangrove systems are also presented in Kristensen et al. (in press). Sediment $\delta^{13} \mathrm{C}$ signatures in mangroves are often distinctly more ${ }^{13} \mathrm{C}$-enriched to those of mangrove litter inputs, and conversely, sediment $\delta^{13} \mathrm{C}$ data from seagrass beds are consistently ${ }^{13} \mathrm{C}$-depleted relative to the dominant seagrass vegetation. POC = particulate organic matter.

very strong spatial variation. A survey of mud crabs at different distances from key habitats found that distance to seagrass, and not distance to saltmarsh (or mangroves), explained much of the variation (Fig. 3.7). This isotope evidence suggests that, where seagrass is present in shallow tropical waters, carbon from the meadows will have a disproportionately high contribution to animal nutrition, whereas further from meadows and where no seagrass exists, animals rely on a generalized carbon pool from a variety of sources.

\subsubsection{Scales of carbon transfer among systems}

The source of energy to consumers and its movement among habitats has been a key focus in ecology. Carbon is expected to move more in aquatic than terrestrial systems because water acts as an efficient transport medium (Polis et al. 1997). In practice, however, the degree to which carbon is transported and utilized in food webs varies among systems. 
Fig. 3.7 Relationships between carbon stable isotope ratios $\left(\delta^{13} \mathrm{C}\right)$ of mud crabs Scylla serrata and the distance crabs were caught from the nearest patch of three habitats (seagrass, saltmarsh, mangroves). The strongest relationship is with seagrass distance, and for this habitat exploded views of small distances show the tight relationship. No relationship exists for saltmarsh or mangroves. Data from Waltham and Connolly (unpubl.).

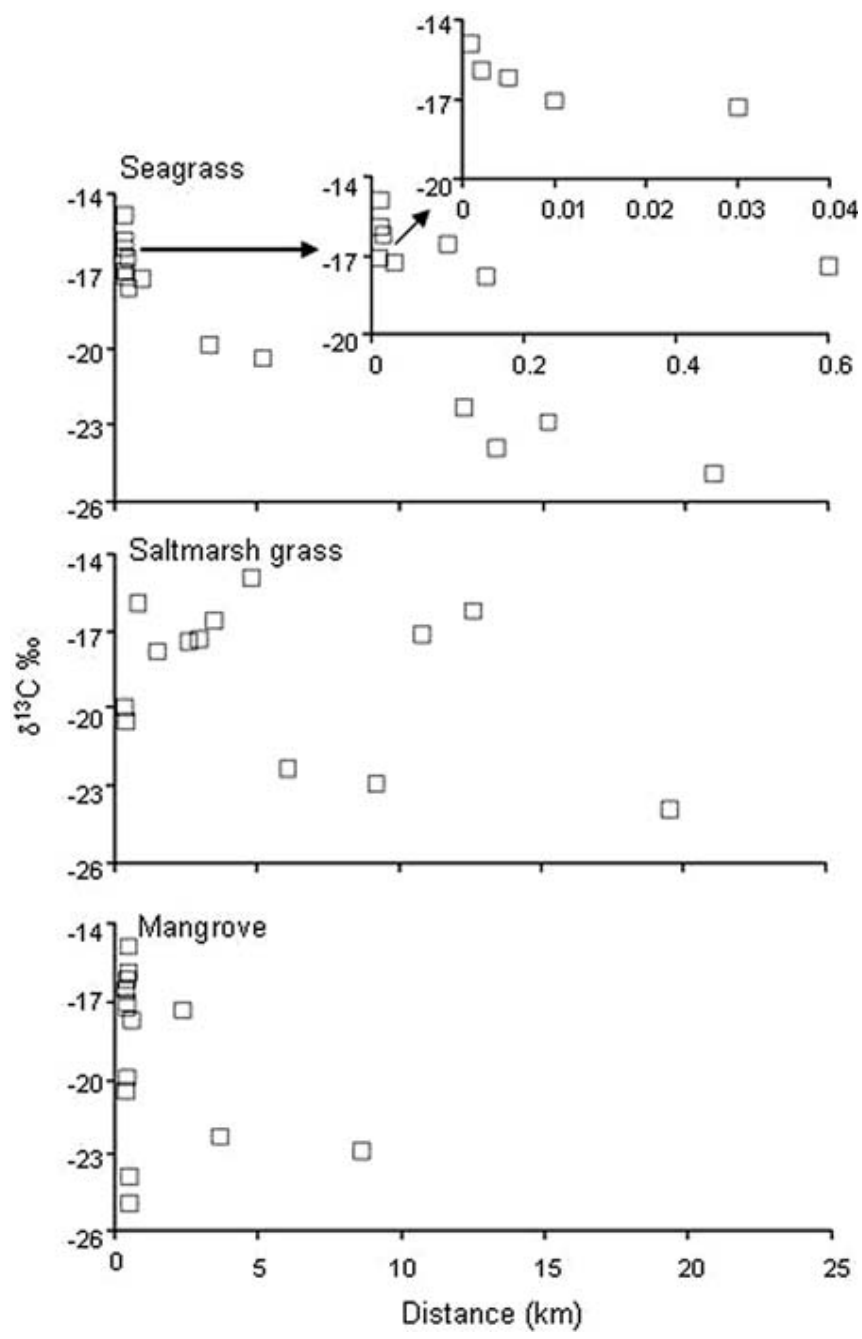

First, the extent of carbon dispersal from river plumes to coastal ecosystems depends on flow rates. Major rivers such as the Amazon River affect pelagic and benthic processes over tens of kilometers (Smith and Demaster 1996). The discharge from smaller rivers, however, can be retained in small, distinct plumes that remain close to the coastline, over an area less than $1 \mathrm{~km}^{2}$ (e.g., Gaston et al. 2006).

Within estuaries themselves, carbon is potentially moved on tidal currents. The amount of carbon available to move has been difficult to quantify, because of high rates of allochthonous input from riverine sources and autochthonous production from often extensive fringing vegetation, and high secondary productivity and, therefore, consumption of carbon. Depending on season and lo- 
cation, mangrove carbon has been detected as detritus in sediment at between 2 and $4 \mathrm{~km}$ from mangrove forests, using both stable isotope (Rodelli et al. 1984) and fatty acid (Meziane et al. 2006) techniques.

For some estuaries, however, the large scale movement of carbon expected from the outwelling theory has not been substantiated (e.g., Loneragan et al. 1997). More recent evidence suggests that the movement of carbon in estuarine habitats can occur at a finer scale than has previously been considered. For example, in a tropical study examining the carbon isotopes of shore crabs at sites separated by hundreds of meters, Hsieh et al. (2002) found that the crabs derive their

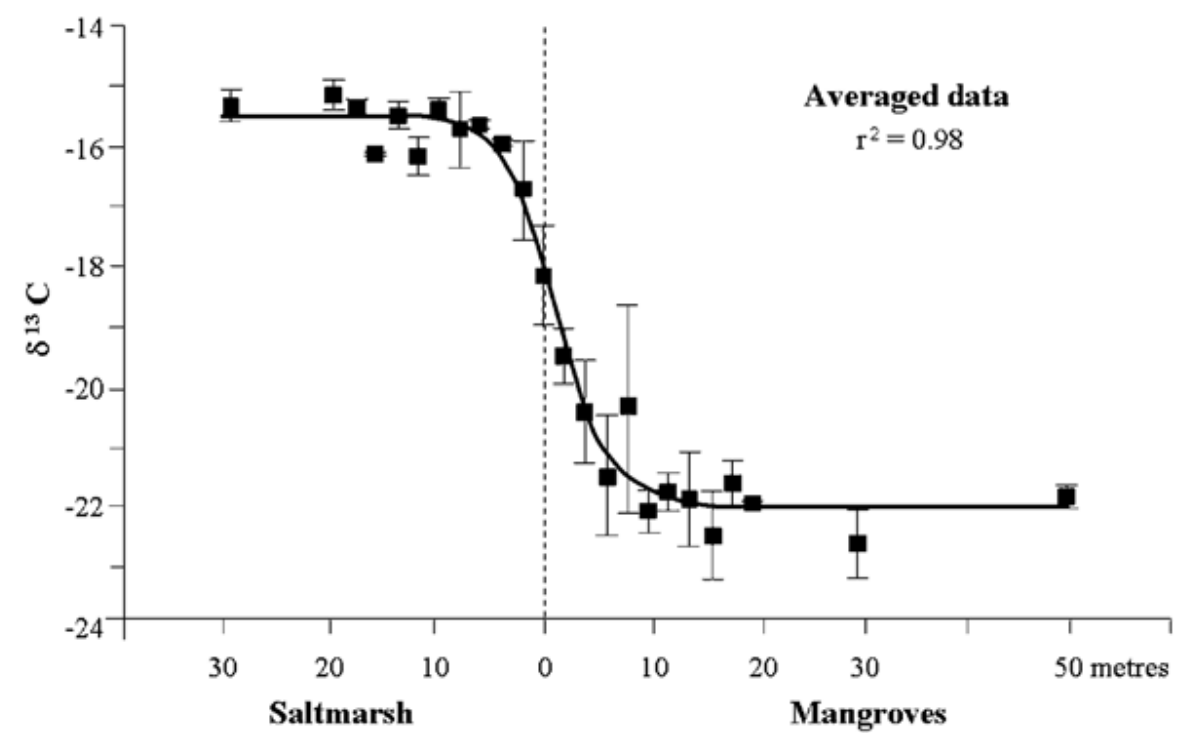

Fig. 3.8 Carbon stable isotope values of the grapsid crab Parasesarma erythrodactyla across the mangrove/saltmarsh interface ((mean \pm SE) from 3 sites; after Guest and Connolly 2004). The rapid change at the interface indicates that crabs utilize different carbon (energy) sources in the two habitats

carbon from the sites in which they reside rather than from further afield. A subsequent study of the movement and assimilation of carbon by shore crabs in a subtropical estuary showed that crabs obtain their nutrition from sources within the surrounding few meters (Fig. 3.8). Detailed measurements of crab and POM movement suggests that the short distance carbon is transported occurs through movement of POM rather than crabs, which have a very small foraging area (Guest et al. 2004, Guest et al. 2006). 


\subsubsection{Carbon exchange in coral reefs}

Compared to other tropical coastal ecosystems, very few studies have addressed the exchange of carbon between coral reefs and adjacent waters (Gattuso et al. 1998).

Delesalle et al. (1998) estimated for a French Polynesian coral reef system that $47 \%$ of organic matter production and $21 \%$ of carbonate production was exported, the latter being in agreement with previous estimates by Smith et al. (1998; 25\%). These numbers were considered minimum estimates, since they did not consider DOC exchange, exchange of macro-debris, and since their measurements were carried out during relatively calm weather conditions and only considered export towards the ocean on the outer part of this fringing reef. The extensive sampling setup by Delesalle et al. (1998) also revealed that horizontal and downslope advection of particles was the dominant pathway of export, rather than vertical transport offshore. The latter is also supported by the data in Hata et al. (1998, 2002), who estimated that only about $20-35 \%$ of the POC exported from reef flats was recovered in sediment traps at $40-50 \mathrm{~m}$ depth at some distance outside the reefs.

Hata et al. (1998) estimated that the net export rate of organic carbon from a coral reef in Palau represented about $4 \%$ of the gross primary production, but this study considered only export of particulate organic carbon and not DOC. Furthermore, since the majority of gross primary production is generally respired in such systems (up to $94 \%$, estimated by Hata et al. 2002), this may still represent a significant part of the (relatively small) net organic carbon production. Hata et al. (2002), for example, estimated that the majority of net community production (80 to 100\%) was exported as DOC or POC, with DOC fluxes being 5 to 6 times higher than POC fluxes. Considering the open character of coral reefs, such a high degree of export, in particular of the DOC produced within these systems, is not entirely surprising. Coral cays can act, however, to trap and store carbon. Pile (2005) showed on the Great Barrier Reef, for example, that almost all of the ultrananoplankton in ambient water is removed by filter feeding organisms on the coral reefs in one pass of the water over the reef. This powerful filtering role suggests net uptake of carbon on reefs, at least over short periods, once the activities of all sessile organisms are taken into account. Similarly, de Goeij and van Duyl (2008) found that the surface of coral reef cavities (including the associated biota) can act as net sinks of DOC.

Export of the excess organic carbon production in the form of living biomass (e.g., juvenile fish migrating to other environments to complete their life cycle) has been proposed to be a major component of the organic matter export in coral reefs (50 to 75\%, see Gattuso et al. 1998), as well as export of drifting algae in systems where algae are an important component of the reef (Kilar and Norris 1988, see also Hata et al. 1998). 


\subsection{Conclusions and future research directions}

Tropical and subtropical coastal ecosystems are characterized by intense primary production and a high degree of carbon exchange on various spatial scales, which can be abiotically driven (flux of particulate and dissolved material) as well as biologically driven (animal movement and trophic relay). The past few decades have seen an increased awareness of the role of the tropical coastal zone in global carbon budgets. We are still far from being able to constrain this role in quantitative terms, however, because of: 1) the complexity of assessing material fluxes and combining this with information on the origin of the material considered, and 2) the diversity of ecosystems in the tropical coastal zone (estuaries, lagoons, mangroves, mudflats, seagrass beds, and coral reefs). These factors necessitate a range of approaches and analytical techniques to adequately address their biogeochemical functioning. Moreover, assessing the importance of biologically mediated carbon exchange is complex and has only rarely been attempted in quantitative terms. Even carbon budgeting efforts for individual ecosystems are hampered by a striking scarcity of data on basic processes such as primary production (e.g., Bouillon et al. 2008b), water-atmosphere $\mathrm{CO}_{2}$ fluxes (e.g., Borges et al. 2005), or carbon burial rates (Duarte et al. 2005). The collection of baseline data from a range of tropical coastal ecosystems thus remains important as a complement to state-of-the art analytical techniques to trace and quantify carbon exchange (see Chapter 13, Section 13.4).

One area in which carbon pathways are yet to be used but should prove effective is as indicators of ecosystem health. The goal of conservation should be about more than species conservation, and should also conserve ecological processes. There is very little guidance in the aquatic conservation literature on what processes might really be important (or measurable). Carbon transfer and utilization is probably central; for example, the source of an animal's food is one of the central organizing themes in ecology (Polis et al. 1997), and a range of tracer tools are available to elucidate carbon pathways (see Chapter 13). As carbon pathways are better understood, it will be possible to detect changes in these pathways due to disturbances such as eutrophication, land-use change in catchments (C4 agriculture), clearing of coastal habitats such as mangroves, and accidental destruction of seagrass through dredging and land claims.

Carbon isotopes are already being used to study ecosystem health in tropical inland waters. In the headwaters of pristine rivers, food webs are supported predominantly by allochthonous input of riparian vegetation (the original river continuum concept by Vannote et al. 1980). In tropical streams, once riparian vegetation is removed, the fundamental pathways are altered, from the original reliance on allochthonous inputs of macrophytes to autochthonous in-stream production, usually of microalgae which rapidly increase production because of greater light availability (Douglas et al. 2005).

Degraded estuarine habitats are beginning to be restored in tropical areas, for example in the Florida Everglades restoration project. Such efforts usually incorporate monitoring of flora and fauna assemblages, but these can be poor indicators of ecological processes. The degree to which restored habitat mimics ecologi- 
cal processes in natural habitat is best measured directly. Again, carbon pathways are an obvious candidate, since they are relatively easily measured using chemical tracers and can be predicted from models based on data from other, less perturbed systems (Twilley et al. 1999).

\section{References}

Ahmad Adnan N, Loneragan NR, Connolly RM (2002) Variability of, and the influence of environmental factors on, the recruitment of postlarval and juvenile Penaeus merguiensis in the Matang mangroves of Malaysia. Mar Biol 141:241-251

Alongi DM (1987) The influence of mangrove-derived tannins on intertidal meiobenthos in tropical estuaries. Oecologia 71:537-540

Alongi DM (1990) Effect of mangrove detrital outwelling on nutrient regeneration and oxygen fluxes in coastal sediments of the central Great Barrier Reef lagoon. Estuar Coast Shelf Sci 31:581-598

Alongi DM, Christoffersen P (1992) Benthic infauna and organism-sediment relations in a shallow, tropical coastal area - influence of outwelled mangrove detritus and physical disturbance. Mar Ecol Prog Ser 81:229-245

Arthington AH, Bunn SE, Poff NL et al (2006) The challenge of providing environmental flow rules to sustain river ecosystems. Ecol Applic 16:1311-1318

Ayukai T, Miller D, Wolanski E et al (1998) Fluxes of nutrients and dissolved and particulate organic carbon in two mangrove creeks in northeastern Australia. Mangroves and Salt Marshes 2:223-230

Baker R, Sheaves M (2005) Redefining the piscivore assemblage of shallow estuarine nursery habitats. Mar Ecol Prog Ser 291:197-213

Baum A, Rixen T, Samiaji J (2007) Relevance of peat draining rivers in central Sumatra for the riverine input of dissolved organic carbon into the ocean. Estuar Coast Shelf Sci 73:563-570

Borges AV, Delille B, Frankignoulle M (2005), Budgeting sinks and sources of $\mathrm{CO}_{2}$ in the coastal ocean: diversity of ecosystems counts. Geophys Res Lett 32, L14601, doi:10.1029/2005GL023053

Borges AV, Djenidi S, Lacroix G et al (2003) Atmospheric $\mathrm{CO}_{2}$ flux from mangrove surrounding waters. Geophys Res Lett 30, 1558, doi: 10.1029/ 2003GL017143

Boto KG, Wellington JT (1988) Seasonal variations in concentrations and fluxes of dissolved organic and inorganic materials in a tropical, tidally dominated waterway. Mar Ecol Prog Ser 50:151-160

Bouillon S, Dahdouh-Guebas F, Rao AVVS et al (2003) Sources of organic carbon in mangrove sediments : variability and possible implications for ecosystem functioning. Hydrobiologia 495:33-39

Bouillon S, Moens T, Dehairs F (2004) Carbon sources sustaining benthic mineralization in mangrove and adjacent seagrass sediments (Gazi bay, Kenya). Biogeosciences 1:71-78

Bouillon S, Dehairs F, Velimirov B et al (2007a) Dynamics of organic and inorganic carbon across contiguous mangrove and seagrass systems (Gazi bay, Kenya). J Geophys Res 112, G02018, doi:10.1029/2006JG000325

Bouillon S, Dehairs F, Schiettecatte LS et al (2007b) Biogeochemistry of the Tana estuary and delta (northern Kenya). Limnol Oceanogr 52:46-59

Bouillon S, Middelburg JJ, Dehairs F et al (2007c) Importance of intertidal sediment processes and porewater exchange on the water column biogeochemistry in a pristine mangrove creek (Ras Dege, Tanzania). Biogeosciences 4:311-322

Bouillon S, Connolly R, Lee SY (2008a). Organic matter exchange and cycling in mangrove ecosystems: recent insights from stable isotope studies. J Sea Res, 59:44-58 
Bouillon S, Borges AV, Castañeda-Moya E et al (2008b). Mangrove production and carbon sinks: a revision of global budget estimates. Glob Biogeochem Cycles, in press

Chong VC, Low CB, Ichikawa T (2001) Contribution of mangrove detritus to juvenile prawn nutrition: a dual stable isotope study in a Malaysian mangrove forest. Mar Biol 138: 77-86

Chua TE (1992) Coastal aquaculture development and the environment: the role of coastal area management. Mar Pollut Bull 25:98-103

Cifuentes LA, Coffin RB, Solorzano L et al (1996) Isotopic and elemental variations of carbon and nitrogen in a mangrove estuary. Estuar Coast Shelf Sci 43:781-800

Cloern JE (2001) Our evolving conceptual model of the coastal eutrophication problem. Mar Ecol Prog Ser 210:223-253

Connolly RM, Gorman D, Guest MA (2005) Movement of carbon among estuarine habitats and its assimilation by invertebrates. Oecologia 144:684-691

Connolly RM, Lee SY (2007) Mangroves and saltmarsh. In: Connell SD, Gillanders BM (eds) Marine Ecology. Oxford University Press, Oxford, p 485-512

Coynel A, Seyler P, Etcheber H et al (2005) Spatial and seasonal dynamics of total suspended sediment and organic carbon species in the Congo River. Glob Biogeochem Cycles 19, GB4019, doi:10.1029/2004GB002335

Dai J, Sun M-Y (2007) Organic matter sources and their use by bacteria in the sediments of the Altamaha estuary during high and low discharge periods. Org Geochem 38:1-15

Daniel PA, Robertson AI (1990) Epibenthos of mangrove waterways and open embayments : community structure and the relationship between exported mangrove detritus and epifaunal standing stocks. Estuar Coast Shelf Sci 31:599-619

Darnaude AM, Salen-Picard C, Harmelin-Vivien ML (2004) Depth variation in terrestrial particulate organic matter exploitation by marine coastal benthic communities off the Rhone River delta (NW Mediterranean). Mar Ecol Prog Ser 275:47-57

Davis III SE, Childers DL, Day JW et al (2001) Wetland-water column exchanges of carbon, nitrogen, and phosphorus in a southern Everglades dwarf mangrove. Estuaries 24:610-622

de Boer WF (2000) Biomass dynamics of seagrasses and the role of mangrove and seagrass vegetation as different nutrient sources for an intertidal ecosystem. Aquat Bot 66:225-239

de Goeij JM, van Duyl FC (2008) Coral cavities are sinks of dissolved organic carbon (DOC). Limnol Oceanogr 52:2608-2617

Delesalle B, Buscail R, Carbonne J et al (1998) Direct measurements of carbon and carbonate export from a coral reef ecosystem (Moorea Island, French Polynesia). Coral Reefs 17:121132

Dittmar T, Lara RJ (2001a) Driving forces behind nutrient and organic matter dynamics in a mangrove tidal creek in North Brazil. Estuar Coast Shelf Sci 52:249-259

Dittmar T, Lara RJ (2001b) Do mangroves rather than rivers provide nutrients to coastal environments south of the Amazon River? Evidence from long-term flux measurements. Mar Ecol Prog Ser 213:67-77

Dittmar T, Lara RJ, Kattner G (2001) River or mangrove ? Tracing major organic matter sources in tropical Brazilian coastal waters. Mar Chem 73:253-271

Dittmar T, Hertkorn N, KattnerG et al (2006) Mangroves, a major source of dissolved organic carbon to the oceans. Glob Biogeochem Cycles 20:GB1012, doi: 10.1029/2005GB002570

Douglas MM, Bunn SE, Davies MP (2005) River and wetland food webs in Australia's wet-dry tropics: general principles and implications for management. Mar Freshwat Res 56:329-342

Duarte CM, Middelburg JJ, Caraco N (2005), Major role of marine vegetation on the oceanic carbon cycle. Biogeosciences 2:1-8

Eyre B (1998) Transport, retention and transformation of material in Australian estuaries. Estuaries 21:540-551

Ford P, Tillman P, Robson B et al (2005) Organic carbon deliveries and their flow-related dynamics in the Fitzroy estuary. Mar Pollut Bull 51:119-127

Fry B, Mumford PL, Robblee MB (1999) Stable isotope studies of pink shrimp (Farfantepenaeus duorarum Burkenroad) migrations on the southwestern Florida shelf. Bull Mar Sci 65:419430 
Galy V, France-Lanord C, Beysacc O et al (2007) Efficient organic carbon burial in the Bengal fan sustained by the Himalayan erosional system. Nature 450:407-410

Gaston TF, Schlacher TA, Connolly RM (2006) Flood discharges of a small river into open coastal waters: plume traits and material fate. Estuar Coast Shelf Sci 69:4-9

Gattuso JP, Frankignoulle M, Wollast R (1998) Carbon and carbonate metabolism in coastal aquatic ecosystems. Ann Rev Ecol Syst29:405-434

Gillanders BM, Kingsford MJ (2002) Impact of changes in flow of freshwater on estuarine and open coastal habitats and the associated organisms. Oceanogr Mar Biol Ann Rev 40:233-309

Goñi MA, Monacci N, Gisewhite R et al (2006) Distribution and sources of particulate organic matter in the water column and sediments of the Fly River Delta, Gulf of Papua (Papua New Guinea). Estuar Coast Shelf Sci 69:225-245

Gonneea ME, Paytan A, Herrera-Silveira JA (2004) Tracing organic matter sources and carbon burial in mangrove sediments over the past 160 years. Estuar Coast Shelf Sci 61:211-227

Guest MA, Connolly RM (2004) Fine-scale movement and assimilation of carbon in saltmarsh and mangrove habitat. Aquat Ecol 38:599-609

Guest MA, Connolly RM, Lee SY et al (2006) Mechanism for the small-scale movement of carbon among estuarine habitats: organic matter transfer not crab movement. Oecologia 148:8896

Guest MA, Connolly RM, Loneragan NR (2004) Carbon movement and assimilation by invertebrates in estuarine habitats occurring at a scale of metres. Mar Ecol Prog Ser 278:27-34

Harrigan P, Zieman JC, Macko SA (1989) The base of nutritional support for the grey snapper (Lutjanus griseus) - an evaluation based on a combined stomach content and stable isotope analysis. Bull Mar Sci 44:65-77

Hata H, Kudo S, Yamano H et al (2002) Organic carbon flux in Shiraho coral reef (Ishigaki Island, Japan). Mar Ecol Prog Ser 232:129-140

Hata H, Suzuki A, Maruyama T et al (1998) Carbon flux by suspended and sinking particles around the barrier reef of Palau, Western Pacific. Limnol Oceanogr 43:1883-1893

Hemminga MA, Mateo MA (1996) Stable carbon isotopes in seagrasses: variability in ratios and use in ecological studies. Mar Ecol Prog Ser 140:285-298

Hemminga MA, Nieuwenhuize J (1991) Transport, deposition and in situ decay of seagrasses in a tropical mudflat area (Banc d'Arguin, Mauretania). Neth J Sea Res 27:183-190

Hemminga MA, Slim FJ, Kazungu J et al (1994) Carbon outwelling from a mangrove forest with adjacent seagrass beds and coral reefs (Gazi Bay, Kenya). Mar Ecol Prog Ser 106:291-301

Hollingsworth A, Connolly RM (2006) Feeding by fish visiting inundated subtropical saltmarsh. J Exp Mar Biol Ecol 336:88-98

Hsieh HL, Chen CP, Chen YG et al (2002) Diversity of benthic organic matter flows through polychaetes and crabs in a mangrove estuary: delta C-13 and delta S-34 signals. Mar Ecol Prog Ser 227:145-155

Hung JJ, Huang MH (2005) Seasonal variations of organic-carbon and nutrient transport through a tropical estuary (Tsengwen) in southwestern Taiwan. Environ Geochem Health 27:75-95

Hutchings PA, Saenger P (1987). Ecology of mangroves. University of Queensland Press, Brisbane.

Hyland J, Balthis L, Karakassis I et al (2005) Organic carbon content of sediments as an indicator of stress in the marine benthos. Mar Ecol Prog Ser 295:91-103

Kilar JA, Norris JN (1988) Composition, export, and import of drift vegetation on a tropical, plant-dominated, fringing-reef platform (Caribbean Panama). Coral Reefs 7:93-103

Kneib RT (1997) The role of tidal marshes in the ecology of estuarine nekton. Oceanogr Mar Biol Ann Rev 35:163-220

Kneib RT (2000) Saltmarsh ecoscapes and production transfers by estuarine nekton in the southeastern U. S. In: Weinstein MP, Kreeger DA (eds) Concepts and controversies in tidal marsh ecology. Kluwer Academic, Netherlands, p 267-292

Kristensen E, Bouillon S, Dittmar T et al (in press) Organic matter dynamics in mangrove ecosystems. Aquat Bot, in press 
Kruitwagen G, Nagelkerken I, Lugendo BR et al (2007) Influence of morphology and amphibious life-style on the feeding ecology of the mudskipper Periophthalmus argentilineatus. J Fish Biol 71:39-52

Kuramoto T, Minagawa M (2001) Stable carbon and nitrogen isotopic characterization of organic matter in a mangrove ecosystem on the south-western coast of Thailand. J Oceanogr $57: 421-431$

Lee SY (1995) Mangrove outwelling - a review. Hydrobiologia 295:203-212

Lee SY (1999) The effect of mangrove leaf litter enrichment on macrobenthic colonization of defaunated sandy substrates. Estuar Coast Shelf Sci 49:703-712

Lee SY (2000) Carbon dynamics of Deep Bay, eastern Pearl River estuary, China. II: Trophic relationship based on carbon- and nitrogen-stable isotopes. Mar Ecol Prog Ser 205:1-10

Loneragan NR, Bunn SE (1999) River flows and estuarine ecosystems: Implications for coastal fisheries from a review and a case study of the Logan River, southeast Queensland. Aust J Ecol 24:431-440

Loneragan NR, Bunn SE, Kellaway DM (1997) Are mangroves and seagrasses sources of organic carbon for penaeid prawns in a tropical Australian estuary? A multiple stable isotope study. Mar Biol 130:289-300

Ludwig W, Amiotte-Suchet P, Probst JL (1996b) River discharges of carbon to the world's oceans: determining local inputs of alkalinity and of dissolved and particulate organic carbon. C R Acad Sci Paris II 323:1007-1014

Ludwig W, Probst JL, Kempe S (1996a) Predicting the oceanic input of organic carbon by continental erosion. Glob Biogeochem Cycles 10:23-41

Lugendo BR, Nagelkerken I, Kruitwagen G et al (2007) Relative importance of mangroves as feeding habitats for fishes: A comparison between mangrove habitats with different settings. Bull Mar Sci 80:497-512

Machiwa JF (1999) Lateral fluxes of organic carbon in a mangrove forest partly contaminated with sewage wastes. Mangroves and Salt Marshes 3:95-104

Machiwa JF (2000) 13C signatures of flora, macrofauna and sediment of a mangrove forest partly affected by sewage wastes. Tanz J Sci 26:15-28

MacIntyre HL, Geider RJ, Miller DC (1996) Microphytobenthos: The ecological role of the "secret garden" of unvegetated, shallow-water marine habitats. 1.Distribution, abundance and primary production. Estuaries 19:186-201

Marguillier S, van der Velde G, Dehairs F et al (1997) Trophic relationships in an interlinked mangrove-seagrass ecosystem as traced by $\delta^{13} \mathrm{C}$ and $\delta^{15} \mathrm{~N}$. Mar Ecol Prog Ser 151:115-121

Martinelli LA, Ballester MV, Krusche AV et al (1999) Landcover changes and $\delta^{13} \mathrm{C}$ composition of riverine particulate organic matter in the Piracicaba river basin (southeast region of Brazil). Limnol Oceanogr 44:1826-1833

Melville AJ, Connolly RM (2003) Spatial analysis of stable isotope data to determine primary sources of nutrition for fish. Oecologia 136:499-507

Melville AJ, Connolly RM (2005) Food webs supporting fish over subtropical mudflats are based on transported organic matter not in situ microalgae. Mar Biol 148:363-371

Meziane T, d'Agata F, Lee SY (2006) Fate of mangrove organic matter along a subtropical estuary: small-scale exportation and contribution to the food of crab communities. Mar Ecol Prog Ser 312:15-27

Middelburg JJ, Nieuwenhuize J, Slim FJ et al (1996) Sediment biogeochemistry in an East African mangrove forest (Gazi Bay, Kenya). Biogeochemistry 34:133-155

Middelburg JJ, Barranguet C, Boschker HTS et al (2000) The fate of intertidal microphytobenthos carbon: an in situ ${ }^{13} \mathrm{C}$-labeling study. Limnol Oceanogr 45:1224-1234

Milliman JD, Farnsworth KL, Albertin CS (1999) Flux and fate of fluvial sediments leaving large islands in the East Indies. J Sea Res 41:97-107

Nagelkerken I, van der Velde G (2004) Are Caribbean mangroves important feeding grounds for juvenile reef fish from adjacent seagrass beds? Mar Ecol Prog Ser 274:143-151

Odum EP (1968) Evaluating the productivity of coastal and estuarine water Proceedings of the Second Sea Grant Conference, University of Rhode Island, p 63-64 
Ovalle ARC, Rezende CE, Lacerda LD et al (1990) Factors affecting the hydrochemistry of a mangrove tidal creek, Sepetiba Bay, Brazil. Estuar Coast Shelf Sci 31:639-650

Pennings S, Bertness M (2001) Salt marsh communities. In: Bertness M, Gaines S, Hay M (eds) Marine community ecology. Sinauer, Mass., p 289-316

Pile AJ (2005) Overlap in diet between co-occurring active suspension feeders on tropical and temperate reefs. Bull Mar Sci 76:743-749

Polis GA, Anderson WB, Holt RD (1997) Toward and integration of landscape and food web ecology: The dynamics of spatially subsidized food webs. Ann Rev Ecol Syst 28:289-316

Poloczanska ES, Babcock RC, Butler A et al (2007) Climate change and Australian marine life. Oceanogr Mar Biol Annu Rev 45:407-478

Postel SL (2000) Entering an era of water scarcity: the challenges ahead. Ecol Appl 10:941-948

Ralison O, Dehairs F, Middelburg JJ et al (2008) Carbon dynamics in the Betsiboka estuary (northwestern Madagascar). Org Geochem, in press.

Rezende CE, Lacerda LD, Ovalle ARC et al (1990) Nature of POC transport in a mangrove ecosystem : a carbon stable isotopic study. Estuar Coast Shelf Sci 30:641-645

Rodelli MR, Gearing JN, Gearing PJ, Marshall N, Sasekumar A. (1984) Stable isotope ratio as a tracer of mangrove carbon in Malaysian ecosystems. Oecologia 61:326-333

Romigh MA, Davis SE, Rivera-Monroy VH et al (2006) Flux of organic carbon in a riverine mangrove wetland in the Florida coastal Everglades. Hydrobiologia 569:505-516

Schefuß E, Versteegh GJM, Jansen JHF et al (2004) Lipid biomarkers as major source and preservation indicators in SE Atlantic surface sediments. Deep-Sea Res I 51:1199-1228

Schlünz B, Schneider RR (2000) Transport of terrestrial organic carbon to the oceans by rivers: re-estimating flux- and burial rates. Int J Earth Sci 88:599-606

Schwendenmann L, Riecke R, Lara RL (2006) Solute dynamics in a North Brazilian mangrove: the influence of sediment permeability and freshwater input. Wetl Ecol Manag14:463-475

Sheaves M, Molony B (2000) Short-circuit in the mangrove food chain. Mar Ecol Prog Ser 199:97-109

Slim FJ, Hemminga MA, Cocheret de la Morinière E et al (1996) Tidal exchange of macrolitter between a mangrove forest and adjacent seagrass beds (Gazi Bay, Kenya). Neth J Aquat Ecol 30:119-128

Smith WO, Demaster DJ (1996) Phytoplankton biomass and productivity in the Amazon River plume - correlation with seasonal river discharge. Cont Shelf Res 16:291-319

Staunton-Smith J, Robins JB, Mayer DG et al (2004) Does the quantity and timing of fresh water flowing into a dry tropical estuary affect year-class strength of barramundi (Lates calcarifer) ? Mar Freshwat Res 55:787-797

Sutula MA, Perez BC, Reyes E et al (2003) Factors affecting spatial and temporal variability in material exchange between the Southern Everglades wetlands and Florida Bay. Estuar Coast Shelf Sci 57:757-781

Thimdee W, Deein G, Sangrungruang C et al (2003) Sources and fate of organic matter in Khung Krabaen Bay (Thailand) as traced by 13C and C/N atomic ratios. Wetlands 23:729-738

Thresher RE, Nichols PD, Gunn JS et al (1992) Seagrass detritus as the basis of a coastal planktonic food chain. Limnol Oceanogr 37:1754-1758

Twilley RR (1985) The exchange of organic carbon in basin mangrove forests in a southwest Florida estuary. Estuar Coast Shelf Sci 20:543-557

Twilley RR, Rivera-Monroy VH, Chen R et al (1999) Adapting an ecological mangrove model to simulate trajectories in restoration ecology. Mar Poll Bull 37:404-419

Twilley RR, Rivera-Monroy VH, Chen R et al (1999) Adapting an ecological mangrove model to simulate trajectories in restoration ecology. Mar Poll Bull 37:404-419

Vance DJ, Haywood MDE, Heales DS et al (1998) Seasonal and annual variation in abundance of postlarval and juvenile banana prawns, Penaeus merguiensis, and environmental variation in two estuaries in tropical northeastern Australia: a six-year study. Mar Ecol Prog Ser 163:21-36

Vannote RL, Minhall GW, Cummins JW et al (1980) The river continuum concept. Can J Fish Aquat Sci 37:130-137 
Xu Y, Jaffé R (2007) Lipid biomarkers in suspended particles from a subtropical estuary: assessment of seasonal changes in sources and transport of organic matter. Mar Environ Res 64:666-678

Young M, Gonneea ME, Herrera-Silveira J et al (2005) Export of dissolved and particulate carbon and nitrogen from a mangrove-dominated lagoon, Yucatan Peninsula, Mexico. Int J Ecol Environm Sci 31:189-202 